\title{
Cognitive Styles, Gender, and Student Academic Performance in Engineering Education
}

\author{
Chaham Alalouch
}

Citation: Alalouch, C. Cognitive Styles, Gender, and Student Academic Performance in Engineering Education. Educ. Sci. 2021, 11, 502. https://doi.org/ 10.3390/educsci11090502

Academic Editor: João Piedade

Received: 4 August 2021

Accepted: 31 August 2021

Published: 3 September 2021

Publisher's Note: MDPI stays neutral with regard to jurisdictional claims in published maps and institutional affiliations.

Copyright: (C) 2021 by the author. Licensee MDPI, Basel, Switzerland. This article is an open access article distributed under the terms and conditions of the Creative Commons Attribution (CC BY) license (https:// creativecommons.org/licenses/by/ $4.0 /)$.
Department of Civil and Architectural Engineering, College of Engineering, Sultan Qaboos University, Muscat 123,Oman; c.alalouch@squ.edu.om

\begin{abstract}
Cognitive styles affect the learning process positively if tasks are matched to the cognitive style of learners. This effect becomes more pronounced in complex education, such as in engineering. We attempted to critically assess the effect of cognitive styles and gender on students' academic performance in eight engineering majors to understand whether a cognitive style preference is associated with certain majors. We used the Cognitive Style Indicator (CoSI) with a sample of $n=584$ engineering students. Multiple standard statistical tests, regression tree analysis, and cluster analysis showed that none of the three cognitive styles was exclusively associated with better performance. However, students who had a stronger preference for a cognitive style were more likely to perform better. Gender, the major, and students' clarity about their cognitive style were shown to be the best predictors of academic performance. Female students performed better and were clearer about their preferred cognitive style, whereas male students were more capable of adapting to different learning tasks. Furthermore, certain engineering majors were shown to be associated with certain cognitive styles. We concluded the study with theoretical and practical implications for engineering education and suggestions for further research.
\end{abstract}

Keywords: engineering pedagogy; cognitive style indicator; CoSI; cognitive theories; higher education; Oman

\section{Introduction}

Engineering education is a complex, multi-faceted process within which several internal and external factors interact to shape student performance [1,2]. It requires that students attain a high level of cognition, advanced problem-solving skills, and an effective information processing ability. Lucas and Hanson [3], in their study on optimizing engineering education, identified six ways that engineers think and act, i.e., habits of the mind [4,5], which are: systems-thinking, adapting, problem-finding, creative problemsolving, visualizing, and improving. In addition, calls were made to support the idea that engineers need to be long-life learners and good communicators [6]. This reflects the complexity in engineering education and amplifies the effect of personal constructs, such as cognitive styles, on a student's learning processes.

In fact, the focus in this area is largely on learning styles, intelligence, and social influences. There was also a strong emphasis on discipline-specific teaching practices $[7,8]$ and cognitively responsive teaching [9]. However, research in the field of cognitive psychology suggests that a person's cognitive style does affect his/her performance in an important way; and that individuals prefer tasks and decision-making processes that are compatible with their cognitive styles $[10,11]$. Despite this, most of the research, which explored the effect of cognitive styles on individual performance, was focused on human resource implications within organizations, such as team performance, productivity, adaptability, and entrepreneurial attitude, to mention a few [12-14]. Cognitive style studies in engineering education are scarce and seem to focus on the student's cognitive level [15], cognitive operations [16], personality traits and mental skills [17], and learning styles [18]. Less at- 
tention was given to the role of a student's cognitive styles in their academic performance, especially in engineering education.

The importance of exploring the relationship between cognitive styles and academic performance in engineering education is supported by the body of knowledge that suggests that cognitive styles are relatively fixed traits $[19,20]$, unlike other learning dispositions that are capable of development and change through education, such as learning styles and habits of mind [3]. It is particularly important for this study to not confuse cognitive styles with learning styles. Although the term learning styles is often used inappropriately as an umbrella term to describe approaches to studying, including cognitive and learning styles, the European Learning Styles Information Network (ELSIN) differentiates between the two [21]. ELSIN follows the definitions provided by Peterson, et al. [22] who defined cognitive styles as "individual differences in processing that are integrally linked to a person's cognitive system... they are a person's preferred way of processing ... they are partly fixed, relatively stable and possibly innate preferences". Learning styles, on the other hand, was defined as "an individual's preferred way of responding (cognitively and behaviorally) to learning tasks which change depending on the environment or context".

According to a review by Curry [19], there are three categories of psychometric qualities that influence learning, namely, instructional preferences, information processing style, and cognitive style (Figure 1). Although this model was later criticized [23], it still provides an overarching model for learning processes. Curry argued that cognitive style is more stable and more significant in complex learning, while instructional preference is less important in learning and easy to modify [24]. Although few studies suggested that students are likely to develop or adopt new learning strategies when there is a mismatch between a task and their preferred cognitive style, the role of cognitive style in the learning process is still important, particularly in the early stages of study [20]. Therefore, providing a better understanding of this important, yet ambiguous, relationship between cognitive style preference and academic performance is likely to yield theoretical and practical consequences in teaching practices, curriculum development, and assessment methods in engineering design pedagogy.

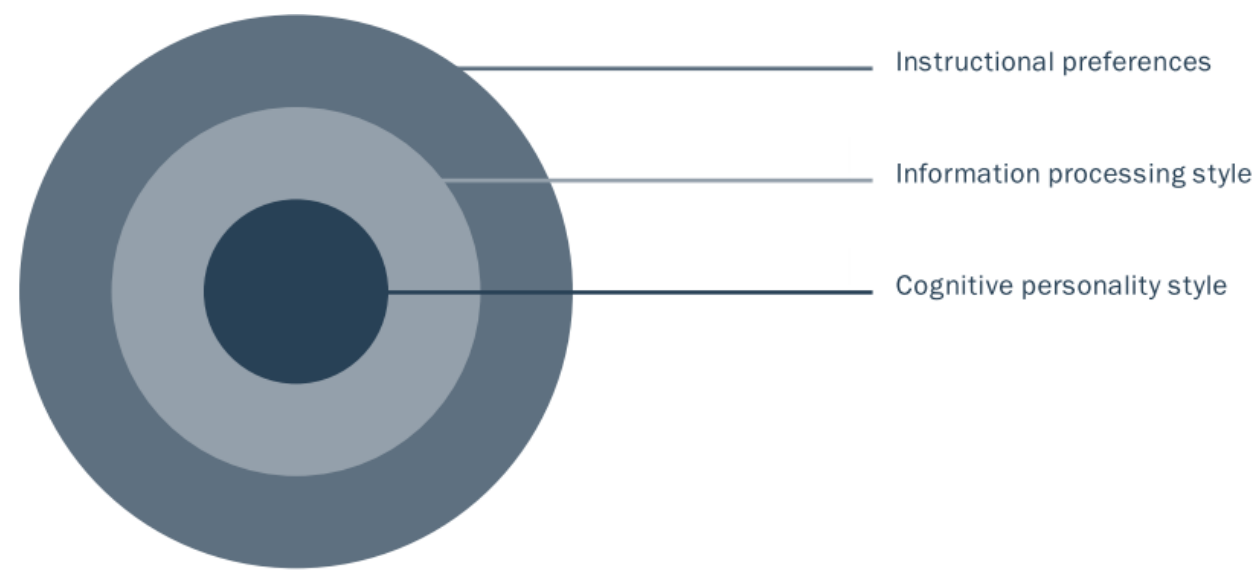

Figure 1. Curry's model of psychometric qualities in learning [24].

Therefore, the aim of this study was to explore the nature of the relationship between students' cognitive styles and their academic performance in engineering education. It was also of interest to this study to explore whether gender, academic probation status, and/or engineering major were associated with differences in students' cognitive styles and their academic performance. The second aim was motivated by the large body of knowledge that explores gender differences in engineering education, technology, and science (see for example [25-29]).

We used the Cognitive Style Indicator [30] to assess the cognitive style of a sample of engineering students at Sultan Qaboos University, Muscat, Oman, in eight basic engineering 
majors and non-specialized students. We tested the independency of the cognitive styles to ensure meaningfulness of the subsequent analysis using principal component analysis. Then, we used inferential statistical analysis, including regression tree and latent cluster analysis, to address the research aims.

\section{Background on Cognitive Styles}

The term "cognitive style" refers to a person's preferred method of thinking, organizing, and representing information within the mind [31]; and it represents heuristics used to regulate cognitive resources [32]. It was first introduced by Allport [33] and was taken further by Witkin [34]. Witkin et al. [35] defined cognitive style as the way an individual perceives, thinks, learns, solves problems, and relates to others. Later, Cools and Broeck [30], p. 360, defined cognitive style as "the way people perceive stimuli and how they use this information to guide their behavior (i.e., thinking, feeling, actions)".

One characteristic of a person's cognitive style is that it is an inbuilt, relatively fixed preference $[19,20]$, and it is a consistent individual difference in how people process and organize information [30]. The notion of stability in the cognitive style is supported by an EEG alpha study [36] and another longitudinal study presented by Clapp [37]. Additionally, several studies found differences between people's learning, perception, creativity, decision making, problem-solving, innovation, and entrepreneurship abilities as a consequence of differences in cognitive styles [13,38-40]. Another characteristic of a person's cognitive style is that it seems to be independent of personality [41]. However, earlier works suggested that cognitive style and some key components of personality interacted in an intermediate area, which was called the "personality space" by Kirton and de Ciantis [42].

The orthodoxical understanding of cognitive style is that they follow a unidimensional model. This model was advocated by several authors in an attempt to introduce order and organize the many constructs associated with cognitive styles based on the assumption that different cognitive styles are governed by the same underlying dimension and are merely different conceptualizations for that dimension $[43,44]$. Although this unidimensional classification indicates a continuum, the two qualities that define this continuum are often treated as a dichotomy. An example of bipolar models include Barnard's logical-nonlogical model [45], the analytical-nonanalytic model of Kemler-Nelson [46], the analytic-holistic model of Beyler and Schmeck [47], the cognitive styles index (CSI) analysis-intuition model [43,48], and Kirton's adaption-innovation model [38,39]. All of these models seem to refer to the same characteristics of the two qualities that represent the two poles of cognitive styles. In a reference to the bipolar unidimensional model of cognitive styles, Cools and Broeck stated that the "first cognitive style is commonly described by the terms analytical, deductive, rigorous, constrained, convergent, formal, and critical. The second cognitive style is commonly described as synthetic, inductive, expansive, unconstrained, divergent, informal, diffuse, and creative" [30], p. 362. Therefore, the first pole (i.e., the analysis style) refers to a preference towards making decisions based on mental reasoning and known facts with great attention given to details; while the other pole (i.e., the intuition cognitive style) indicates a more holistic perspective and a preference for judgment based on feelings and perception.

Despite the convenience associated with dealing with cognitive styles as a dichotomy, the model showed significant limitations. Some authors emphasized the continuum nature of the proposed bipolar model of cognitive styles, which indicates the possibility for individuals to vary in the extent to which they prefer a certain cognitive style. This possibility was not available in the model since the dichotomist view eliminated the possibility for an individual to show simultaneous preference for more than one of the two poles of the dimension [49]. Equally important, Sadler-Smith [50] argued that a single bipolar overarching dimension might not be capable of explaining the complexity of the differences among people.

Therefore, several multidimensional models were developed, such as Riding's cognitive styles analysis (CSA) [51-54], which is a computerized two-dimensional assessment 
model that measures holist-analytic and verbalizer-imager dimensions. The model assumes the independence of the two dimensions. Several authors questioned the reliability of the model and provided evidence that the reliability of CSA is low [55-57]. Moreover, Coffield et al. highlighted unresolved conceptual issues with Riding's model [24]. On the contrary, Cools and Broeck developed a validated model of cognitive styles, namely, the Cognitive Style Indicator (CoSI) [30].

\section{Cognitive Style Indicator (CoSI)}

The Cognitive Style Indicator (CoSI) was developed as a response to the need for a validated and reliable multidimensional cognitive style assessment instrument that recognized the continuum-like nature of cognitive styles and captured the complexity associated with individual differences, in line with developments in the cognitive style and cognitive psychology fields [58]. Upon development, Cools and Broeck [30] provided strong evidence of the validity of the model using three diverse and large samples that included managers, employees, and students. The study showed that the model had a high level of internal consistency, homogeneity, discriminant validity, and criterion-related validity. This study was followed by a cross-culture study that further demonstrated the validity of the model [59].

The CoSI is a simple 18 item, self-reporting instrument. It uses a 5-point Likert scale to measure three cognitive styles i.e., knowing, planning, and creating. The contribution of CoSI to the literature on cognitive style models is twofold. At a theoretical level, Cools and Broeck [30] refined the analytic-intuitive unitary dimension of Allinson and Hayes by splitting the analytic style into knowing and planning [43]. At a methodological level, they provided a validated and simple instrument to assess cognitive styles preference.

In CoSI, the knowing style is strongly related to rationality, indicating a preference for logical, analytical, and impersonal information processing. People with the knowing style look for facts and data and they pay great attention to details. They make decisions and generate solutions based on data and facts. The planning style is associated with organization and preparation. People with the planning style prefer rules and regulations, step-by-step explanations, and consistent procedures. They dislike ambiguity and prefer clarity and order. The creating style indicates a robust tendency towards experimentation and freedom in problem-solving. People with the creating style tend to be creative, flexible, innovative and they accept uncertainty and prefer dynamic structures [30].

The CoSI was used widely in several fields including entrepreneurship orientation [60], growth intention [61], attitude toward e-learning [62], and task performance and distraction [63]. To the best of our knowledge, this study is the first to use CoSI in the context of engineering to explore the relationship between students' cognitive styles, gender, and academic performance in engineering education.

\section{Materials and Methods}

The study instrument consisted of a two-section self-reporting survey. The first section asked about demographics, academic probation, and the student's cumulative grade-points average (CGPA). A student is considered as being on academic probation if his/her CGPA falls under $2 / 4$. In the second section, we used the original CoSI survey and a 5-point agreement scale, as suggested by Cools and Broeck [30]. As an internal validity procedure, we added two "no-brainer" statements (no. 1 and no. 13). The idea was to be able to spot, and consequently exclude, the click-through answers. These two statements asked about the same issue using different paraphrasing [64]. The issue chosen for the "nobrainer" statements was the preference for group work since it was not related to any other statements (Table 1).

The survey was administered online and on paper with students from the College of Engineering at Sultan Qaboos University. Each round included different cohorts. Students were invited to complete the survey via email. The researcher then visited the classes to encourage students to complete the survey. It was made clear to students that taking 
the survey was not obligatory and that it was anonymous. Eight engineering majors were included in the study: civil, architectural, petroleum and natural gas, chemical and process, mechanical, industrial, electrical and computer, and mechatronics. In addition, non-specialized students who were in the college's preparatory year were included. In total, 584 completed surveys were received, but only 540 were retained and considered useful.

Table 1. Cognitive Style Indicator (CoSI) items and the "no-brainer" statements.

\begin{tabular}{|c|c|c|}
\hline Code & Statement & Cognitive Style \\
\hline K1 & I want to have a full understanding of all problems. & \multirow{4}{*}{ Knowing Style } \\
\hline K2 & I like to analyze problems. & \\
\hline $\mathrm{K} 3$ & I make detailed analysis. & \\
\hline K4 & I study each problem until I understand the underlying logic. & \\
\hline P1 & Developing a clear plan is very important to me. & \multirow{7}{*}{ Planning Style } \\
\hline $\mathrm{P} 2$ & I always want to know what should be done when. & \\
\hline P3 & I like detailed action plans. & \\
\hline $\mathrm{P} 4$ & I prefer clear structures to do my job. & \\
\hline P5 & $\begin{array}{l}\text { I prefer well-prepared meetings with a clear agenda and strict } \\
\text { time management. }\end{array}$ & \\
\hline P6 & I make definite engagement, and I follow up meticulously. & \\
\hline P7 & A good task is a well-prepared task. & \\
\hline $\mathrm{C} 1$ & I like to contribute to innovative solutions. & \multirow{7}{*}{ Creating Style } \\
\hline $\mathrm{C} 2$ & I prefer to look for creative solutions. & \\
\hline $\mathrm{C} 3$ & I am motivated by ongoing innovation. & \\
\hline $\mathrm{C} 4$ & I like much variety in my life. & \\
\hline C5 & New ideas attract me more than existing solutions. & \\
\hline C6 & I like to extend boundaries. & \\
\hline C7 & I try to avoid routine. & \\
\hline / & I always prefer to work in a group. & \multirow{2}{*}{ "no-brainer" } \\
\hline / & I always prefer to work individually. & \\
\hline
\end{tabular}

The sample breakdown is shown in Table 2. Efforts were made to ensure that the distribution of the sample was proportionate to the number of students across majors. In addition, the sample size was notably more than the minimum accepted rule-of-thumb for non-parametric tests i.e., 15 items in each group [65]. The descriptive statistics showed that the average CGPA was 2.85/4 with a standard error of 0.26 and a standard deviation of 0.53 .

The data were analyzed using SPSS and Latent GOLD 5.1. We started with a simple descriptive analysis to provide an overview of the data. Then, we conducted principal component analysis (PCA) with varimax rotation on cognitive styles to check their independency in our sample and to ensure that the underlying structure of our data supported the subsequent inferential statistics. We then tested the normality of the data and used a series of statistical tests to address the research aims. 
Table 2. Sample breakdown $(n=540)$.

\begin{tabular}{|c|c|c|c|}
\hline & Variables & Frequency & Percentage $(\%)$ \\
\hline \multirow[b]{2}{*}{ Gender } & Male & 335 & 62 \\
\hline & Female & 205 & 38 \\
\hline \multirow{6}{*}{ Cohort } & 2011 & 28 & 5.3 \\
\hline & 2012 & 91 & 17.2 \\
\hline & 2013 & 109 & 20.6 \\
\hline & 2014 & 75 & 14.2 \\
\hline & 2015 & 108 & 20.4 \\
\hline & 2016 & 119 & 22.5 \\
\hline \multirow{5}{*}{ Department } & Civil and Architectural Engineering (CAE) & 167 & 30.9 \\
\hline & Petroleum and Chemical Engineering (PCE) & 79 & 14.6 \\
\hline & Mechanical and Industrial Engineering (MIE) & 47 & 8.7 \\
\hline & Electrical and Computer Engineering (ECE) & 87 & 16.1 \\
\hline & None Specialized (None) & 160 & 29.6 \\
\hline \multirow{9}{*}{ Engineering Major } & Civil Engineering (CE) & 104 & 19.3 \\
\hline & Architectural Engineering (AE) & 63 & 11.7 \\
\hline & Chemical and Processing Engineering (ChE) & 63 & 11.7 \\
\hline & Petroleum and Natural Gas Engineering (PE) & 24 & 4.4 \\
\hline & Mechanical Engineering (ME) & 19 & 3.5 \\
\hline & Industrial Engineering (IE) & 28 & 5.2 \\
\hline & Electrical and Computer Engineering (EE) & 51 & 9.4 \\
\hline & Mechatronics Engineering (MeE) & 28 & 5.2 \\
\hline & Not specialized (None) & 160 & 29.6 \\
\hline Have you even been on & Yes & 93 & 17.2 \\
\hline Academic Probation? & No & 447 & 82.8 \\
\hline
\end{tabular}

\section{Results}

\subsection{Preliminary Analysis}

\subsubsection{Descriptive Analysis}

Table 3 summarizes the mode, median, inter-quartile rank, and nominal level of agree vs. disagree for the 18 survey items, as recommended by Jamieson [66] when analyzing Likert data. This method of analysis was also used in research related to higher education pedagogy [67].

Table 3. Initial analysis of survey data based on [66]. For the full description of each variable, refer to Table 1.

\begin{tabular}{|c|c|c|c|c|c|c|c|c|c|c|c|c|c|c|c|c|c|c|}
\hline & \multicolumn{4}{|c|}{ Knowing Style } & \multicolumn{7}{|c|}{ Planning Style } & \multicolumn{7}{|c|}{ Creating Style } \\
\hline & K1 & $\mathrm{K} 2$ & K3 & K4 & P1 & $\mathbf{P 2}$ & P3 & $\mathbf{P 4}$ & P5 & P6 & P7 & $\mathrm{C} 1$ & $\mathrm{C} 2$ & $\mathrm{C} 3$ & $\mathrm{C} 4$ & $\mathrm{C} 5$ & C6 & C7 \\
\hline Median & 5 & 4 & 4 & 4 & 4 & 4 & 4 & 4 & 4 & 4 & 4 & 4 & 4 & 4 & 4 & 4 & 4 & 4 \\
\hline Mode & 5 & 4 & 4 & 4 & 4 & 5 & 4 & 5 & 4 & 4 & 5 & 4 & 4 & 4 & 4 & 5 & 4 & 4 \\
\hline Q1-Q3 & $4-5$ & $4-5$ & $3-4$ & $3-5$ & $4-5$ & $4-5$ & $4-5$ & $4-5$ & $4-5$ & $3-4$ & $4-5$ & $3-5$ & $4-5$ & $3-5$ & $4-5$ & $4-5$ & $3-5$ & $3-5$ \\
\hline Agree \% & 89.6 & 88.6 & 70.1 & 73.5 & 84.8 & 86.3 & 78.7 & 86.8 & 75.4 & 68.7 & 86.6 & 74.2 & 83 & 71.3 & 80.2 & 80.1 & 72.9 & 66.5 \\
\hline Disagree \% & 1.5 & 0.7 & 4.8 & 4.8 & 1.7 & 13.7 & 3.2 & 2.6 & 3.6 & 3.3 & 2.5 & 4.9 & 15 & 3 & 3 & 2.4 & 2.5 & 5.9 \\
\hline
\end{tabular}

Note: Agree and disagree values do not add up to $100 \%$ because of "neutral" answers.

\subsubsection{The Independency of Cognitive Styles}

Although Cools and Broeck [30] provided evidence that CoIS items had a clear structure that is best described by a three-factor solution, it was necessary to test the independency among the three cognitive styles for our sample to ensure meaningful results. Therefore, principal component analysis (PCA) with varimax rotation was performed. Before subjecting the variables to PCA, an additional check on the stability of the data for PCA was performed. Cronbach's alpha for all items was 0.84, supporting the internal reliability of our scale. An inspection of the correlation matrix revealed the presence of 
many coefficients of 0.3 and above. The determinant was 0.019 , which is well above the minimum value of 0.00001 , thereby confirming that multicollinearity was not a problem for our data set [68]. Similarly, the Kaiser-Meyer-Olkin value was 0.86, exceeding the recommended minimum of $0.6[69,70]$, while the and the Barlett's test of sphericity [71] reached statistical significance (chi-square $=2079.59$, and $p<0.00$ ). All of these findings supported the appropriateness of PCA to the correlation matrix.

The result of the PCA model revealed that the three components solution explained a cumulative percentage of $42.54 \%$ of the variance. The rotated solution revealed the presence of a simple structure, with three components showing strong correlational loadings, confirming that the three styles were sufficiently discriminating against each other (Table 4). The result of the PCA aligned with the findings of $[30,61]$. It confirmed the validity of our survey data and that the Likert statements corresponded to the three cognitive styles.

Table 4. Rotated component matrix of CoIS.

\begin{tabular}{|c|c|c|c|c|c|c|c|c|c|c|c|c|c|c|c|c|c|c|c|}
\hline & & \multicolumn{4}{|c|}{ Knowing Style } & \multicolumn{7}{|c|}{ Planning Style } & \multicolumn{7}{|c|}{ Creating Style } \\
\hline & & K1 & $\mathrm{K} 2$ & K3 & K4 & P1 & P2 & P3 & P4 & P5 & P6 & P7 & $\mathrm{C} 1$ & $\mathrm{C} 2$ & $\mathrm{C} 3$ & $\mathrm{C} 4$ & C5 & C6 & C7 \\
\hline \multirow{3}{*}{ Components } & 1 & & & & & 0.57 & 0.62 & 0.68 & 0.68 & 0.58 & 0.42 & 0.53 & & & & & & & \\
\hline & 2 & & & & & & & & & & & & 0.54 & 0.61 & 0.61 & 0.63 & 0.63 & 0.61 & 0.55 \\
\hline & 3 & 0.60 & 0.79 & 0.72 & 0.58 & & & & & & & & & & & & & & \\
\hline
\end{tabular}

Extraction method: principal component analysis. Rotation method: varimax with Kaiser normalization. Suppressed values: $<0.4$ as suggested by [72].

\subsubsection{The Normality of the Variables}

The normality of the distribution of each cognitive style was checked using the onesample Kolmogorov-Smirnov test. The results of the test (Table 5), indicated that the distributions of the three cognitive styles were not normally distributed. Hence, nonparametric tests were used.

Table 5. Test of normality.

\begin{tabular}{cccc}
\hline & Knowing Style & Planning Style & Creating Style \\
\hline K-S statistic & $0.123^{*}$ & $0.094^{*}$ & $0.072 *$ \\
\hline Sig. & 0.00 & 0.00 & 0.00 \\
\hline * Significant values. Note: significant value of K-S test indicates deviation from normality. $\mathrm{df}=534$.
\end{tabular}

\subsection{Differences among Groups in Cognitive Styles}

It is of interest to this study to explore whether gender, academic probation status, and engineering major were associated with differences in students' cognitive styles. An initial insight into the data is illustrated in Figure 2, which shows that both male and female students preferred the planning style, followed by the knowing style. However, female students seemed to be clearer about their preference, with a higher average score across the three styles. In addition, the figure shows that there is a general inclination toward the planning and the knowing styles across all majors. The only exception was the mechatronics engineering program, where the knowing style was clearly preferred over the other two styles, with a higher average across (knowing $=4.28$, planning $=3.9$, and creating $=3.8$ ).

In order to explore whether these differences were statistically significant and due to the non-normal distributions, the non-parametric Mann-Whitney U and Kruskal-Wallis analysis of variance tests were used (Table 6). Firstly, those on academic probation showed no differences in their cognitive style when compared with those who have never been on academic probation. This suggests that none of the three cognitive styles was linked to poor academic performance in our sample, and that being on academic probation was independent of the student's cognitive style. 


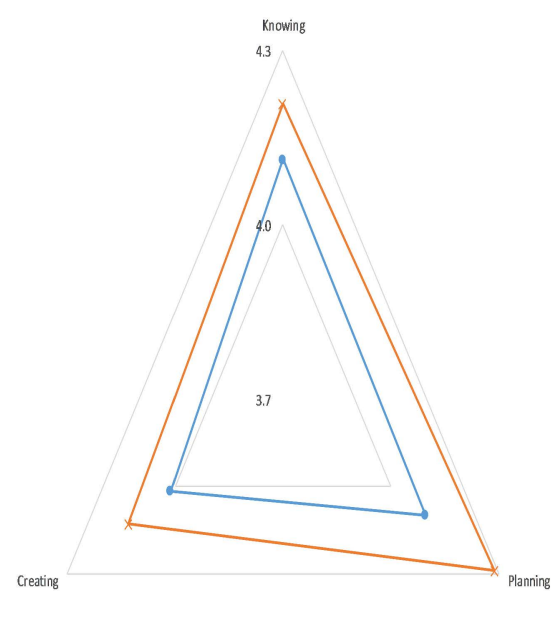

Gender

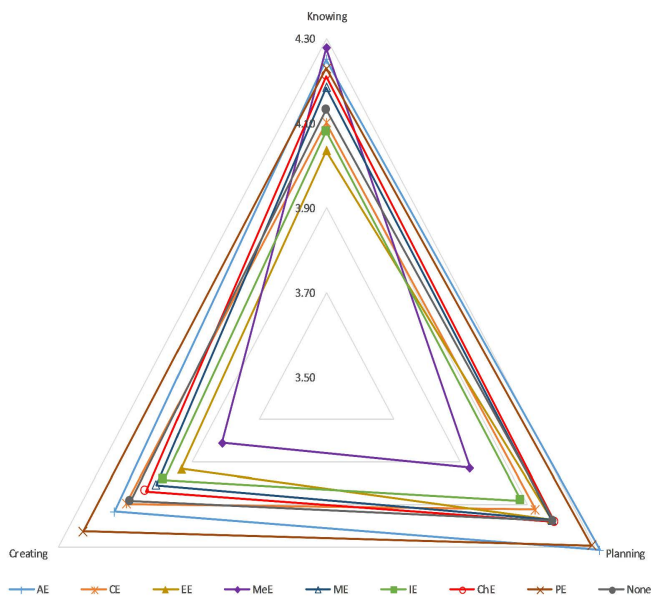

Major

Figure 2. The distribution of cognitive styles across gender and majors (for full department and major names, please refer to Table 2).

Secondly, male and female students in this study reported differences in cognitive style preference. In particular, female students scored significantly higher in the planning style (male mean rank $=245.2$, female mean rank $=310.8, \mathrm{z}=-4.77, p<0.01$ ) and in the creating style (male mean rank $=253.8$, female mean rank $=292.6, \mathrm{z}=-2.82, p<0.01$ ) than male students. Both genders showed no significant differences in the knowing style. These results supported our observation in the initial analysis and suggest that female students have a higher and clearer preference among the two cognitive styles, whereas male students do not seem to have a predominant cognitive style and are more flexible in a way that makes them able to adapt to different learning tasks. 
Table 6. The differences among groups in the cognitive styles.

\begin{tabular}{ccccc}
\hline & & Knowing Style & Planning Style & Creating Style \\
\hline \multirow{2}{*}{${ }^{\text {a Gender }}$} & Mann-Whitney U & 31,101 & $25,847.5$ & $28,919.5$ \\
\cline { 2 - 5 } & Wilcoxon W & 87,381 & $82,127.5$ & $84,530.5$ \\
\cline { 2 - 5 } & Z & -1.767 & $-\mathbf{4 . 7 6 4}$ & $-\mathbf{2 . 8 1 5}$ \\
\cline { 2 - 5 } & Asymp. Sig. (2-tailed) & 0.077 & $\mathbf{0 . 0 0 0}$ & $\mathbf{0 . 0 0 5}$ \\
\hline \multirow{2}{*}{$\begin{array}{c}\text { a Academic } \\
\text { Probation }\end{array}$} & Mann-Whitney U & 18,661 & 19,083 & $18,880.5$ \\
\cline { 2 - 5 } & Wilcoxon W & 23,032 & 23,454 & $23,158.5$ \\
\cline { 2 - 5 } & Asymp. Sig. (2-tailed) & -1.536 & -1.217 & -1.145 \\
\hline b Major & Chi-square & 8.692 & 0.224 & 0.252 \\
\cline { 2 - 5 } & Asymp. Sig. & 0.369 & $\mathbf{1 6 . 5 4} * *$ & 15.611 \\
\cline { 2 - 5 } & Asy & $\mathbf{0 . 0 3 5}$ & 0.05 \\
\hline
\end{tabular}

* Significant values at $0.01,{ }^{* *}$ Significant values at $0.05,{ }^{\text {a }}$ Mann-Whitney U test, ${ }^{\mathrm{b}}$ Kruskal-Wallis test.

Lastly, the planning cognitive style was shown to be associated with the engineering major in which the student is enrolled (chi-square $=16.54, \mathrm{df}=8, p<0.05$ ). The petroleum and natural gas engineering students showed the highest score in the planning style (mean rank $=314.7$ ), followed by the architectural engineering students (mean rank $=310.7$ ). The lowest score was observed in the mechatronics engineering students (mean rank $=185.8$ ). The normalized mean rank for each major is shown in Figure 3.

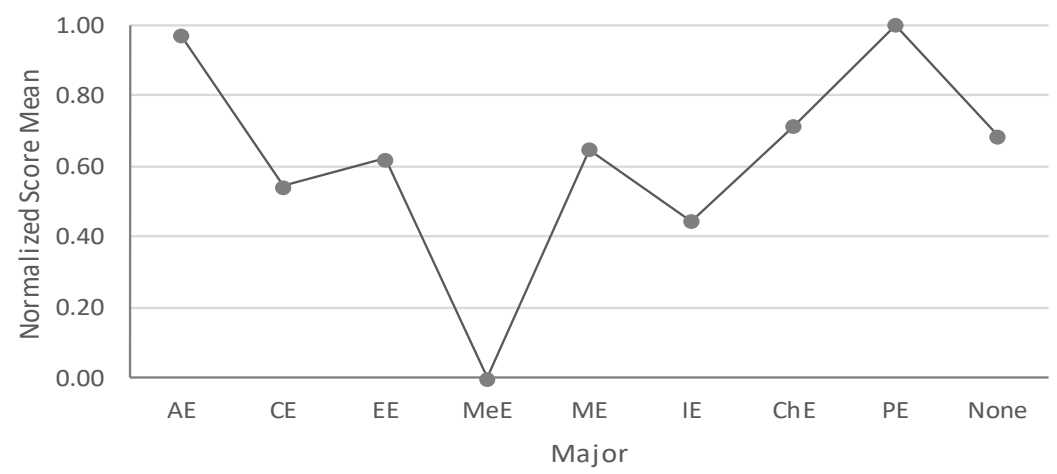

Figure 3. The normalized mean of the planning style scores across engineering majors.

In order to explore this relationship further, a Mann-Whitney test was performed between each pair of majors with the planning style as the dependent variable (Table 7). The results revealed two clear trends in the data:

- The architectural engineering students scored significantly higher than the civil engineering students in the planning style (AE mean rank $=94.1, \mathrm{CE}$ mean rank $=77.2$, $\mathrm{z}=-2.12, p<0.05)$.

- The mechatronics engineering students showed significant differences in the planning style when compared with all other programs, except the industrial engineering, with the mechatronics engineering students scoring significantly less in this style (mean ranks: $\mathrm{MeE} / \mathrm{CE}=53.1 / 70.1 ; \mathrm{MeE} / \mathrm{AE}=30.9 / 52.1 ; \mathrm{MeE} / \mathrm{ChE}=35.5 / 50.7 ; \mathrm{MeE} / \mathrm{PE}=20.4 / 33.6$; $\mathrm{MeE} / \mathrm{ME}=20.7 / 28.9 ; \mathrm{MeE} / \mathrm{EE}=32.1 / 44.3 ;$ and $\mathrm{MeE} / \mathrm{None}=67.9 / 99.2)$. This suggests that the mechatronics students required less structured projects and that their preference to work according to clear rules and systems was lower when compared to the other engineering students. Although it is not clear from this analysis whether mechatronics students prefer the knowing or the creating styles, our earlier analysis suggested that those students are inclined toward the knowing cognitive style. 
Table 7. Differences in the planning style across the programs (for the full major name, please refer to Table 2).

\begin{tabular}{|c|c|c|c|c|c|c|c|c|c|c|}
\hline & & CE & $\mathrm{AE}$ & ChE & PE & ME & IE & $\mathrm{EE}$ & MeE & None \\
\hline CE & $\begin{array}{c}z \\
\text { Sig. }\end{array}$ & & & & & & & & & \\
\hline $\mathrm{AE}$ & $\begin{array}{c}z \\
\text { Sig. }\end{array}$ & $\begin{array}{c}-2.1{ }^{* *} \\
0.028\end{array}$ & & & & & & & & \\
\hline ChE & $\begin{array}{c}z \\
\text { Sig. }\end{array}$ & $\begin{array}{c}-0.88 \\
0.38\end{array}$ & $\begin{array}{l}-1.2 \\
0.25\end{array}$ & & & & & & & \\
\hline PE & $\begin{array}{c}z \\
\text { Sig. } \\
\end{array}$ & $\begin{array}{l}-1.6 \\
0.11 \\
\end{array}$ & $\begin{array}{c}-0.11 \\
0.91 \\
\end{array}$ & $\begin{array}{c}-0.98 \\
0.33 \\
\end{array}$ & & & & & & \\
\hline $\mathrm{ME}$ & $\begin{array}{c}z \\
\text { Sig. }\end{array}$ & $\begin{array}{c}-0.35 \\
0.73\end{array}$ & $\begin{array}{c}-1.05 \\
0.29\end{array}$ & $\begin{array}{c}-0.22 \\
0.83\end{array}$ & $\begin{array}{c}-0.98 \\
0.33\end{array}$ & & & & & \\
\hline IE & $\begin{array}{c}z \\
\text { Sig. }\end{array}$ & $\begin{array}{c}-0.42 \\
0.67 \\
\end{array}$ & $\begin{array}{l}-1.7 \\
0.081 \\
\end{array}$ & $\begin{array}{c}-0.84 \\
0.39 \\
\end{array}$ & $\begin{array}{l}-1.6 \\
0.12 \\
\end{array}$ & $\begin{array}{c}-0.63 \\
0.53\end{array}$ & & & & \\
\hline $\mathrm{EE}$ & $\begin{array}{c}z \\
\text { Sig. }\end{array}$ & $\begin{array}{c}-0.42 \\
0.68\end{array}$ & $\begin{array}{c}-1.58 \\
0.12\end{array}$ & $\begin{array}{c}-0.41 \\
0.68\end{array}$ & $\begin{array}{c}-1.3 \\
0.19\end{array}$ & $\begin{array}{c}-0.08 \\
0.94\end{array}$ & $\begin{array}{c}-0.71 \\
0.48\end{array}$ & & & \\
\hline $\mathrm{MeE}$ & $\begin{array}{c}z \\
\text { Sig. }\end{array}$ & $\begin{array}{c}-2.1 * * \\
0.036\end{array}$ & $\begin{array}{c}-3.6 \text { * } \\
0.00\end{array}$ & $\begin{array}{c}-2.54 \text { * } \\
0.011\end{array}$ & $\begin{array}{c}-3.2 \text { ** } \\
0.002\end{array}$ & $\begin{array}{c}-2.1^{*} \\
0.04\end{array}$ & $\begin{array}{c}-0.83 \\
0.41\end{array}$ & $\begin{array}{c}-2.3 * * \\
0.022\end{array}$ & & \\
\hline None & $\begin{array}{c}z \\
\text { Sig. }\end{array}$ & $\begin{array}{c}-0.97 \\
0.33\end{array}$ & $\begin{array}{c}-1.58 \\
0.11\end{array}$ & $\begin{array}{c}-0.15 \\
0.88\end{array}$ & $\begin{array}{c}-1.17 \\
0.24\end{array}$ & $\begin{array}{c}-0.19 \\
0.85\end{array}$ & $\begin{array}{c}-0.90 \\
0.37\end{array}$ & $\begin{array}{c}-0.36 \\
0.72\end{array}$ & $\begin{array}{c}-2.82 \\
0.005\end{array}$ & \\
\hline
\end{tabular}

* Significant values at 0.01 level. ** Significant values at 0.05 level. Test: Mann-Whitney U.

\subsection{Cognitive Styles and Academic Performance}

In order to provide initial insight into the relationship between the academic performance and cognitive styles, a Spearman correlation coefficient was performed between the CGPA and each of the three cognitive styles (Table 8).

Table 8. The relationship between CGPA and cognitive styles.

\begin{tabular}{ccccc}
\hline & & Knowing & Planning & Creating \\
\hline \multirow{2}{*}{$\begin{array}{c}\text { Cumulative Grade Point } \\
\text { Average (CGPA) }\end{array}$} & Spearman coefficient & 0.192 & 0.190 & 0.098 \\
\cline { 2 - 5 } & Sig. (2-tailed) & $0.000 *$ & $0.000 *$ & $0.000 *$ \\
\hline
\end{tabular}

* Significant values at 0.01 level. Test: Spearman correlation coefficient.

The academic performance was found to correlate positively with the three cognitive styles. This suggests that the academic performance of the students was not associated with a certain cognitive style. However, the correlation coefficients are notably weak (all coefficients were below 0.2) and hence, the results were not conclusive. The scatter plots shown in Figure 4 further reinforce this conclusion.
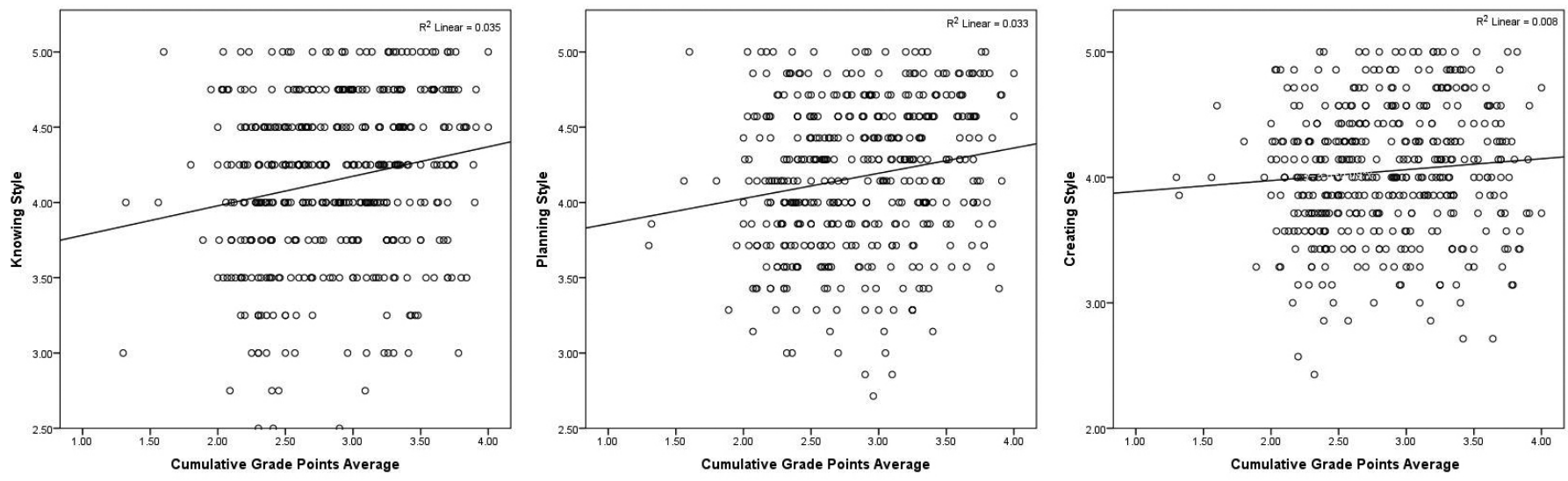

Figure 4. Scatter plots between cumulative grade point average and the three cognitive styles. 
In order to explore the nature of the relationship between academic performance, cognitive styles, and the variables that showed an association with differences in the cognitive styles in the previous analysis, a regression model was required. However, due to the violation of the normality assumption, the nonparametric sequential classification and regression answer tree (CART) was used. This statistical model is based on machine learning algorithms and it provides an optimal sequence of predictive variables as well as an optimal scale point for discrimination of each variable. CART was selected over the chisquare automatic interaction detector (CHAID) as it has a stronger predictive power [73]. This method of analysis was used earlier in several fields, e.g., [74]. Therefore, a decision tree with a CART option was conducted to predict the excellent students (CGPA $\geq 3$ ) from the average students $(\mathrm{CGPA}<3)$, with the following variables acted as potential predictors: gender, major, knowing style, planning style, and creating style. The reason for selecting CGPA of $3 / 4$ as a split point between average students and excellent students is that the College allows students with CGPA of 3 and above to take extra credit due to their excellent academic performance.

The resulted regression tree model predicted $72 \%$ of the cases with a standard error of 0.21 . Figure 5 shows that the model predicted eight profiles of students using three predictors. The best overall predictor of the students' academic performance was the gender, with female students $65.1 \%$ more likely to perform better than male students. The second-best predictor was the major with improvement in the model accuracy of $4.4 \%$ for male and $2.7 \%$ for female. The last predictor was the creating style. However, the contribution of this predictor to model improvement was neglectable $(0.4 \%)$. Therefore, it was concluded that none of the cognitive styles had significantly predicted students' academic performance.

\subsection{Cluster Analysis}

In this section, the focus in on exploring whether there is a combination of factors that form different discrete clusters of students in terms of academic performance, i.e., latent clusters. This was particularly relevant due to a previous analysis that showed that there were differences between groups (male vs. female and average vs. excellent) resulting from a clear preferred cognitive style, regardless of what the style is. In order to explore this, Latent GOLD 5.1 software was used to perform latent class (LC) analysis on the data. This is a type of statistical analysis through which different subgroups of respondents who have common characteristics profile across the variables of the study are identified [75]. The strength of this type of analysis is that it relaxes the assumptions (e.g., homogenousity, normality, and linearity) that are often required by conventional statistical models [76]. Prior to conducting the LC analysis, a new dichotomous variable was driven from the data to distinguish those who showed confidence about their preferred cognitive style and those who were less conclusive. This variable was used in the LC model along with academic performance (average/excellent), the gender, and the major variables. The bootstrap method of cluster membership estimation was used to enhance the model's accuracy.

The LC analysis yielded three significantly distinct latent clusters (Table 9) as determined by the lowest log-likelihood and the number of parameters ( $L L=-1606.21$, $\mathrm{BIC}(\mathrm{LL})=3426.3, \mathrm{Npar}=35, \mathrm{~L} 2=51.35, \mathrm{df}=36, p>0.05)$. The inspection of the bivariate residuals matrix supported the fit of the model to our data with no value was significantly more than the threshold value of one. The four variables were significantly linked to the clusters as shown in the $p$-value column in Table 9. This is aligned with our earlier finding in which gender, major, and clarity of cognitive styles showed association with students academic performance in our sample.

In order to better understand the role of the cognitive styles in the students' academic performance, the cluster memberships were examined (Table 10). First, the table shows that $47 \%$ of the students were in cluster $1,28 \%$ in cluster 2 , and $25 \%$ in cluster 3 . Second, $76 \%$ of the students in cluster 1 were average students in terms of academic performance and $76 \%$ were male hence, cluster 1 was the "male-average" students. Cluster 3 , on the 
other hand, was the "student-excellent" cluster (61\% excellent) and included both male $(22 \%)$ and female (30\%). Cluster 2 contained both average and excellent students, but it consists mostly of female students $(70 \%)$. Examination of the cognitive style exclusiveness variable suggested that members of cluster 1 (male-average cluster) were more likely $(62 \%)$ to not have an exclusive cognitive style, unlike cluster 3 (student-excellent) in which more members were likely to be clear about their preferred cognitive style. The same conclusion was also applicable to cluster 2, which contained both average and excellent female students.

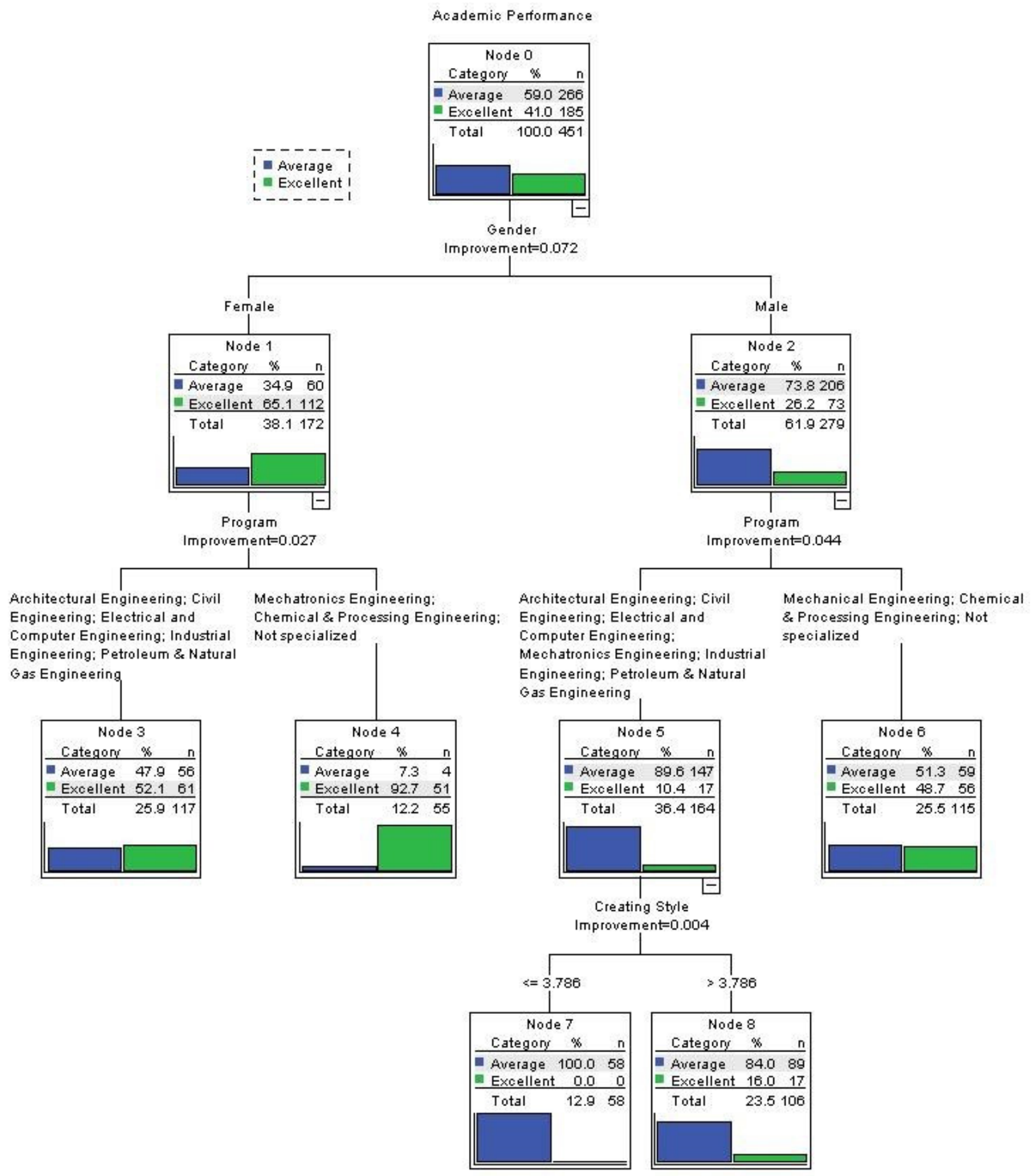

Figure 5. A regression tree (CART) predicting students' academic performance (average student: CGPA $<3$; and excellent student: $\mathrm{CGPA} \geq 3$ ). 
Table 9. The latent clusters with the associated significance of the variables.

\begin{tabular}{cccccc}
\hline Variable & Cluster 1 & Cluster 2 & Cluster 3 & Wald & $p$-Value \\
\hline $\begin{array}{c}\text { Academic } \\
\text { performance }\end{array}$ & -3.818 & -0.667 & 4.485 & $15.56^{*}$ & 0.00 \\
\hline Gender & -4.727 & 3.921 & 0.806 & $6.73^{* *}$ & 0.035 \\
\hline Major & 7.670 & -18.543 & 17.117 & $44.05^{*}$ & 0.00 \\
\hline $\begin{array}{c}\text { Exclusiveness of } \\
\text { cognitive style }\end{array}$ & -0.499 & 0.310 & 0.189 & $7.72 * *$ & 0.02 \\
\hline
\end{tabular}

* Significant values at 0.01 level. ${ }^{* *}$ Significant values at 0.05 level.

Table 10. Clusters size and memberships.

\begin{tabular}{|c|c|c|c|}
\hline & Cluster 1 & Cluster 2 & Cluster 3 \\
\hline Cluster size & 0.4687 & 0.2805 & 0.2507 \\
\hline \multicolumn{4}{|l|}{ Academic Performance } \\
\hline Average & 0.7624 & 0.2360 & 0.0017 \\
\hline Excellent & 0.0469 & 0.3445 & 0.6085 \\
\hline \multicolumn{4}{|l|}{ Gender } \\
\hline Male & 0.7559 & 0.0224 & 0.2217 \\
\hline Female & 0.0033 & 0.6989 & 0.2978 \\
\hline \multicolumn{4}{|l|}{ Major } \\
\hline Civil Engineering (CE) & 0.1032 & 0.8743 & 0.0224 \\
\hline Architectural Engineering (AE) & 0.5166 & 0.3944 & 0.0891 \\
\hline Chemical and Processing Engineering (ChE) & 0.7828 & 0.2037 & 0.0135 \\
\hline Petroleum and Natural Gas Engineering (PE) & 0.6915 & 0.0027 & 0.3058 \\
\hline Mechanical Engineering (ME) & 0.5511 & 0.0001 & 0.4488 \\
\hline Industrial Engineering (IE) & 0.7568 & 0.2385 & 0.0047 \\
\hline Electrical and Computer Engineering (EE) & 0.2107 & 0.1905 & 0.5988 \\
\hline Mechatronics Engineering (MeE) & 0.5309 & 0.4680 & 0.0011 \\
\hline Not specialized (None) & 0.4233 & 0.0009 & 0.5758 \\
\hline \multicolumn{4}{|l|}{ Cognitive Style Exclusiveness } \\
\hline Exclusive & 0.4363 & 0.2998 & 0.2639 \\
\hline Not exclusive & 0.6214 & 0.1899 & 0.1887 \\
\hline
\end{tabular}

In summary, male students who do not have a predominate cognitive style are more likely to achieve lower in their academic performance when compared with male students who have a clearer cognitive style. However, the academic performance of female students seemed to be independent of the exclusiveness of the cognitive style. The profile of the average and excellent students is shown in Figure 6. This finding is aligned with our earlier findings. 


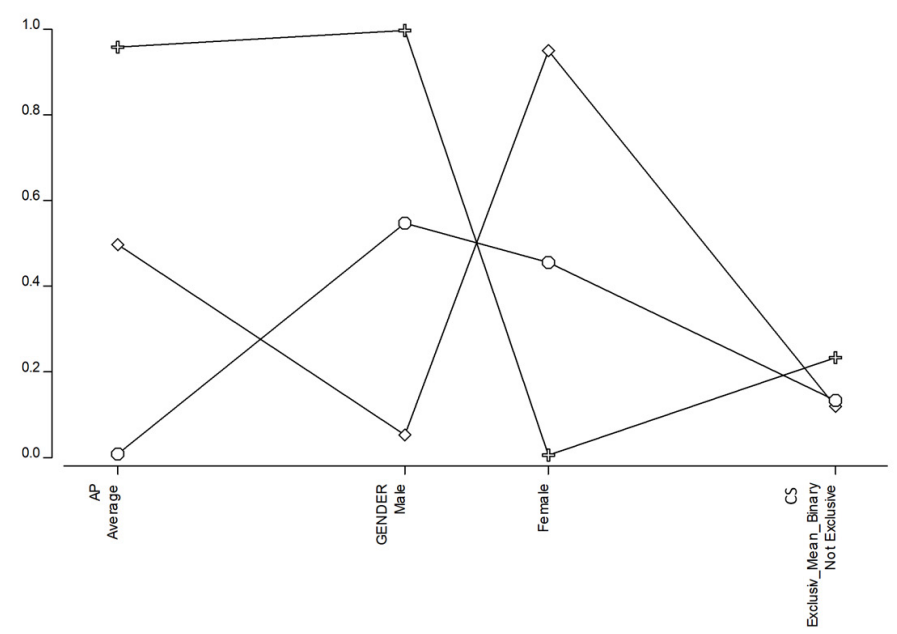

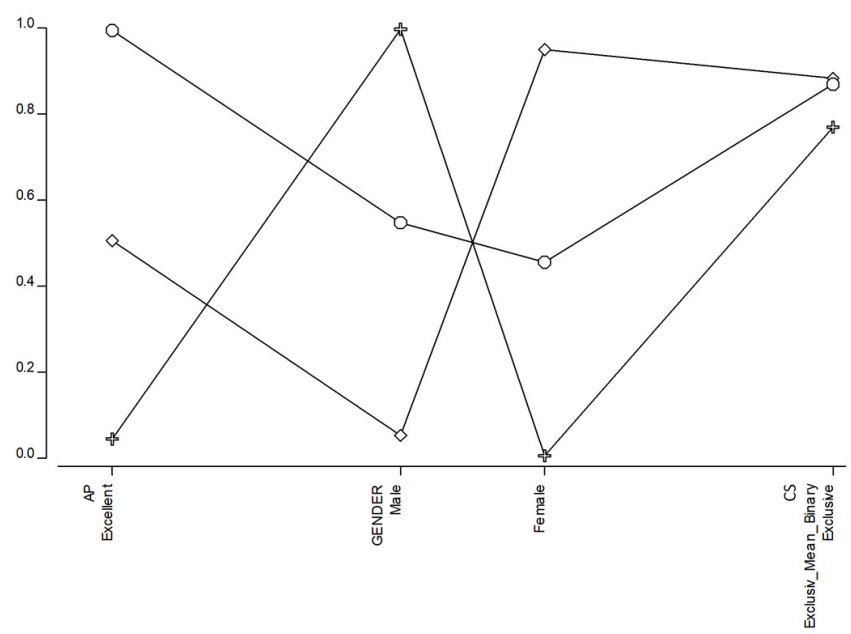

$\begin{array}{ll}\text { Quster1 } & \text { f } \\ \text { Guster2 } & \diamond \\ \text { Quster3 } & 0\end{array}$

Excellent Student Profile

Figure 6. The profile of the average and excellent students.

\section{Discussion and Conclusions}

Since cognitive styles describe the direction of achievement rather than the level of achievement, this study provides insights on how to adapt instructional materials to cognitive styles in order to optimize the engineering learning experience in higher education. Conventionally, the instructional materials and assessment methods in engineering education are designed to achieve the course learning objectives based mainly on the instructor's experience and the departments' guidelines and regulations. It is seldom that students' cognitive styles are considered as input in the design of engineering courses. This is despite the fact that research suggests that cognitive styles are relatively fixed traits and difficult to change, unlike other non-cognitive learning dispositions, and that they affect the learning process positively if the tasks match the cognitive styles of learners, otherwise it hinders it. This is not to say that all tasks should match students' preference, as students tend to develop learning strategies with time to cope with the variation in educational tasks [20]. Our recommendation is that efforts should be made to consider the cognitive styles of students across various courses in engineering majors as another layer of input for course design in order to fine-tune educational tasks and instructional practices to enhance learning. This is aligned with the proposal of Lucas and Hanson [3], who suggested that engineers have a specific way of thinking, which should influence engineering pedagogy. Moreover, considering cognative style in course design has recently become more important due to the need to maximize cognitive engagement when using learning technologies and online teaching that were necessitated by the COVID-19 pandemic.

We view the relationship between students' cognitive styles and course design in engineering as a two-way, multi-stage relationship that should start from a good understanding of the students' cognitive styles, feed into engineering curricula, get evaluated by both students and instructors, and reflect back on the compatibility between class instructional methods and students' cognitive styles. This non-static relationship generates a system by which continuous improvement in course delivery can be periodically evaluated and enhanced.

Our call to integrate students' cognitive styles into course design and delivery methods adds a new admission to Shulman's [7,77] signature pedagogy idea. Shulman called for "types of teaching that organize the fundamental ways in which future practitioners are educated for their new professions" [7], p. 52. It is the "mode of teaching that has become inextricably identified with preparing people for a particular profession" [77], p. 9. He explained that novelty in signature pedagogy in majors such as engineering comes from the subject matter itself. We extend this proposition to emphasize that minimum knowledge 
about student's cognitive styles should team up with the specificity of the subject to enhance novelty and improve learning outcomes in engineering education. This should be supported by a positive learning environment, which was shown to be an important contributor to the academic success of students [78]. In other words, course design, delivery methods, and learning environment should cultivate students' cognitive styles, especially in engineering education where this effect becomes more salient.

This study contributes to this discourse at theoretical and practical levels. At a theoretical level, we found that the three cognitive styles supported the main driving force of engineering design education i.e., "making staff and making stuff work better" [3]. None of the three cognitive styles was found to be exclusively preferred by students on academic probation nor associated with better academic performance. The results suggested that what matters among the variables considered in this study in term of academic performance is gender, major, and students' clarity about their cognitive style. Students who are clearer about their preferred cognitive style are more likely to perform better academically. Moreover, female students performed better and were clearer about their preferred cognitive style, whereas male students were more capable of adaptation to different learning tasks. This particular finding does not aim to propagate stereotyping, but rather to attempt to shed light on the interrelationships between gender, cognitive style, and student academic performance in engineering design education, a topic that is under-studied. In fact, the higher success rate of female students in higher education is well documented in the literature. Several factors were identified explaining these differences, see [29] for a brief review. However, further research is still needed in this area to provide a better explanation for the reasons behind these differences.

At a practical level, we found three interesting findings. Firstly, the petroleum and natural gas engineering students in our sample showed a significantly higher preference toward the planning style, followed by the architectural engineering students. Secondly, students of mechatronics engineering in the study sample showed significantly lower preference towards the planning style when compared to almost all other majors considered in this study. In fact, they showed a tendency toward favoring the knowing style. This style indicates a preference for logical and impersonal information processing. People who prefer the knowing style have great respect for facts. They have an enormous capacity for details and are good at demanding tasks as far as these tasks depend on facts and logic. However, earlier research found that the knowing style was likely to curb entrepreneurial growth intention due to the uncertainty involved in such type of growth intention [61].

Thirdly, the architectural engineering students had a significantly higher preference towards the planning style when compared to civil engineering students. These two programs are often offered under the same department, as in our case study, which suggests that students of architectural engineering in our sample are inclined to be more organized, self-disciplined, and reliable, preferring to study in an organized environment under a rational and analytic cognitive system when compared to the civil engineering students. This might be due to the nature of design tasks and project-based learning that they take during their study in which an overarching process is often followed. Having a preference for the planning style does not necessarily contradict the creativity requirements for design because operating within a certain organized process does not necessarily lead to conventional designs, it rather provides order. Our finding supports the conclusions of Roberts [20], who found that novice students with a tendency to think analytically performed better in architectural design when compared with those who are categorized as "holistic". Roberts et al. used the analytic-holistic model of Riding [51] in which the "holistic" cognitive style was the closest to the creating style in CoSI.

These findings have consequences on teaching practices in these majors. Further research is needed to test and perhaps develop examples of engineering signature teaching that match different cognitive styles. Approaches such as CDIO (conceive-designimplement-operate) or methods, such as problem-based learning (PBL) and project-based learning (PjBL), could form a good starting point. Another point that could be of special 
interest is how certain cognitive styles affect entrepreneurial potential in some engineering majors such as mechatronics. Future research could also explore the relationship between cognitive styles and student engagement. Equally important, our findings regarding the relationship between the exclusiveness of cognitive style and academic performance in engineering students needs to be tested cross-nation and internationally as we do not claim the generalizability of our findings, since the sample size and composition was one of the study limitations.

We are not proposing additional content to engineering curricula, rather we call for a revision of course delivery and instructional methods, educational tasks, and assessment rubrics of design projects in a way that responds to the variety of cognitive styles and accommodates the different ways of processing information. Instructors need to be taught about cognitive styles and how different people process information to be able to cultivate a learning environment in engineering design that takes into account the differences in students' cognitive styles.

Funding: No funding was received for this research.

Data Availability Statement: Due to privacy reasons, the data are not publicly available. Queries about data availability may be directed to the corresponding author.

Acknowledgments: We thank Sultan Qaboos University for its continuous encouragement and support towards research activities, and we extend our gratitude to all students and instructors who supported this work. The survey used in this study obtained the approval of the Sultan Qaboos University VC's Advisor for Academic Affairs on 20 April 2017.

Conflicts of Interest: The author declares no conflict of interest.

\section{References}

1. Winberg, C.; Winberg, S.; Jacob, C.; Garraway, J.; Engel-Hills, P. “I take engineering with me”: Epistemological transitions across an engineering curriculum. Teach. High. Educ. 2016, 21, 398-414. [CrossRef]

2. Alabdulkarem, A.; Alhojailan, M.; Alabdulkarim, S. Comprehensive investigation of factors influencing university students academic performance in Saudi Arabia. Educ. Sci. 2021, 11, 375. [CrossRef]

3. Lucas, B.; Hanson, J. Thinking like an engineer: Using engineering habits of mind and signature pedagogies to redesign engineering education. Int. J. Eng. Pedagog. 2016, 6, 4-13. Available online: https://online-journals.org/index.php/i-jep/article/ view/5366/3948 (accessed on 1 April 2021). [CrossRef]

4. Resnick, L.B. Making America Smarter. 1999. Available online: https://www.edweek.org/ew/articles/1999/06/16/40resnick.h1 8.html (accessed on 2 June 2020).

5. Costa, A.L.; Kallick, B. Discovering and Exploring Habits of Mind; Assn for Supervision \& Curriculum: Alexandria, VA, USA, 2002.

6. Beder, S. Beyond technicalities: Expanding engineering thinking. J. Prof. Issues Eng. Educ. Pract. 1999, 125, 12-18. [CrossRef]

7. Shulman, L.S. Signature pedagogies in the professions. Daedalus 2005, 134, 52-59. [CrossRef]

8. Donnison, S.; Marshman, M. Professional identity formation: Curriculum considerations for inducting undergraduate students into discursive communities. Int. J. Pedagog. Learn. 2013, 8, 58-65. [CrossRef]

9. Michel, J.O. Charting students' exposure to promising practices of teaching about sustainability across the higher education curriculum. Teach. High. Educ. 2020, 1-27. [CrossRef]

10. Gardner, W.; Martinko, M. Using the Myers-Briggs type indicator to study managers: A literature review and research agenda. J. Manag. 1996, 22, 45-83. [CrossRef]

11. Hunt, R.; Krzystofiak, F.; Meindl, J.; Yousry, A. Cognitive style and decision making. Organ. Behav. Hum. Decis. Process. 1989, 44, 436-453. [CrossRef]

12. Volkema, R.J.; Gorman, R.H. The influence of cognitive-based group composition on decision-making process and outcome. J. Manag. Stud. 1998, 35, 105-121. [CrossRef]

13. Hayes, J.; Allinson, C.W. Cognitive style and its relevance for management practice. Br. J. Manag. 1994, 5, 53-71. [CrossRef]

14. Bouckenooghe, D.; Cools, E.; Vanderheyden, K.; Van-den-Broeck, H. In search for the heffalump: An exploration of cognitive style profiles among Flemish entrepreneurs. J. Appl. Manag. Entrep. 2005, 10, 58-75.

15. Jablokow, K.W.; DeFranco, J.F.; Richmond, S.S.; Piovoso, M.J.; Bilen, S.G. Cognitive style and concept mapping performance. J. Eng. Educ. 2015, 104, 303-325. [CrossRef]

16. Meter, P.N.; Firetto, C.M.; Turns, S.R.; Litzinger, T.A.; Cameron, C.E.; Shaw, C.W. Improving students' conceptual reasoning by prompting cognitive operations. J. Eng. Educ. 2016, 105, 245-277. [CrossRef]

17. Bouiri, O.; Lotfi, S.; Talbi, M. Correlative study between personality traits, student mental skills and educational outcomes. Educ. Sci. 2021, 11, 153. [CrossRef] 
18. Abdelhadi, A.; Ibrahim, Y.; Nurunnabi, M. Investigating engineering student learning style trends by using multivariate statistical analysis. Educ. Sci. 2019, 9, 58. [CrossRef]

19. Curry, L. An organization of learning styles theory and constructs. In Proceedings of the Annual Meeting of the American Educational Research Association, Montreal, QC, Canada, 11-15 April 1983.

20. Roberts, A. Cognitive styles and student progression in architectural design education. Des. Stud. 2006, 7, e181. [CrossRef]

21. Evans, C.; Cools, E.; Charlesworth, M.Z. Learning in higher education-How cognitive and learning styles matter. Teach. High. Educ. 2010, 15, 467-478. [CrossRef]

22. Peterson, E.R.; Rayner, S.; Armstrong, S.J. Herding Cats: In Search of Definitions of Cognitive Styles and Learning Styles. 2009. Available online: https:/ / bit.ly/36dMykR (accessed on 5 February 2021).

23. Cools, E.; Bellens, K. The onion model: Myth or reality in the field of individual differences psychology? Learn. Individ. Differ. 2012, 22, 455-462. [CrossRef]

24. Coffield, F.; Moseley, D.; Hall, E.; Ecclestone, K. Learning Styles and Pedagogy in Post-16 Learning: A Systematic and Critical Review; Learning \& Skills Research Centre: London, UK, 2004.

25. Macdonald, A. Not for People Like Me? Under-Represented Groups in Science, Technology and Engineering; WISE: Bradford, UK, 2014.

26. Beneroso, D.; Alosaimi, N. Cultural intelligence of chemical engineering students: A demographics study. Educ. Chem. Eng. 2020, 32, 32-39. [CrossRef]

27. Blickenstaff, J.C. Women and science careers: Leaky pipeline or gender filter? Gend. Educ. 2005, 17, 369-386.

28. Naukkarinen, J.K.; Bairoh, S. STEM: A help or a hinderance in attracting more girls to engineering? J. Eng. Educ. 2002, 109, 177-193. [CrossRef]

29. Hamann, K.; Pilotti, M.A.; Wilson, B.M. What lies beneath: The role of self-efficacy, causal attribution habits, and gender in accounting for the success of college students. Educ. Sci. 2021, 11, 333. [CrossRef]

30. Cools, E.; Broeck, H.V.D. Development and validation of the cognitive style indicator. J. Psychol. Interdiscip. Appl. 2007, 141, 359-387. [CrossRef] [PubMed]

31. Riding, R.; Rayner, S. Cognitive Styles and Learning Strategies: Understanding Style Differences in Learning and Behaviour; David Fulton Publishers: London, UK, 1998.

32. Kozhevnikov, M. Cognitive styles in the context of modern psychology: Toward an integrated framework of cognitive style. Psychol. Bull. 2007, 133, 464-481. [CrossRef]

33. Allport, G.W. Personality: A Psychological Interpretation; Holt \& Co.: New York, NY, USA, 1937.

34. Witkin, H.A. Psychological Differentiation: Studies of Development; Wiley: New York, NY, USA, 1962.

35. Witkin, H.A.; Moore, C.A.; Goodenough, D.R.; Cox, P.W. Field-dependent and field-independent cognitive styles and their educational implications. Rev. Educ. Res. 1977, 47, 1-64. [CrossRef]

36. Riding, R.J.; Glass, A.; Butler, S.R.; Pleydell-Pearce, C.W. Cognitive style and individual differences in EEG alpha during information processing. Educ. Psychol. 1997, 14, 219-234. [CrossRef]

37. Clapp, R.G. Stability of cognitive style in adults and some implications, a longitudinal study of the kirton adaption-innovation inventory. Psychol. Rep. 1993, 73, 1235-1245. [CrossRef]

38. Kirton, M. Adapters and innovators: A description and measure. J. Appl. Psychol. 1976, 61, 622-669. [CrossRef]

39. Kirton, M.J. Adaptation-Innovation in the Context of Diversity and Change; Routledge: London, UK, 2003.

40. Kickul, J.; Gundry, L.; Barbosa, S.; Whitcanack, L. Intuition versus analysis? Testing differential models of cognitive style on entrepreneurial self-efficacy and the new venture creation process. Entrep. Theory Pract. 2009, 33, 439-453. [CrossRef]

41. Riding, R.J. Cognitive style: A review. In International Perspectives on Individual Differences: Cognitive Styles; Ablex Publishing Corporation: New York, NY, USA, 2000.

42. Kirton, M.J.; de Ciantis, S.M. Cognitive style in organizational climate. In Adaptors and Innovators: Styles of Creativity and Problem Solving; Routledge: New York, NY, USA, 1994; pp. 72-90.

43. Allinson, C.W.; Hayes, J. The cognitive style index: A measure of intuition-analysis for organizational research. J. Manag. Stud. 1996, 33, 119-135. [CrossRef]

44. Riding, R.J. On the nature of cognitive style. Educ. Psychol. 1997, 17, 29-49. [CrossRef]

45. Barnard, C.I. The Functions of the Executive; Harvard University Press: Cambridge, UK, 1938.

46. Kemler-Nelson, D.G. The effect of intention on what concepts are acquired. J. Verbal Learn. Verbal Behav. 1984, 23, 734-759. [CrossRef]

47. Beyler, J.; Schmeck, R.R. Assessment of individual differences in preferences for holistic-analytic strategies: Evaluation of some commonly available instruments. Educ. Psychol. Meas. 1992, 52, 709-719. [CrossRef]

48. Allinson, C.; Hayes, J. The Cognitive Style Index: Technical Manual and User Guide, the United Kingdom; Pearson Education Ltd.: London, UK, 2012.

49. Sadler-Smith, E. Cognitive style and the management of small and medium-sized enterprises. Organ. Stud. 2004, 25, 155-181. [CrossRef]

50. Sadler-Smith, E. A duplex model of cognitive style. In Perspectives on the Nature of Individual Preferences; Springer: Berlin/Heidelberg, Germany, 2009; pp. 3-28.

51. Riding, R.J.; Cheema, I. Cognitive styles-An overview and integration. Educ. Psychol. 1991, 11, 193-215. [CrossRef]

52. Riding, R. Cognitive Styles Analysis Users' Manual. Learning and Training Technology; Birmingham, UK, 1991. 
53. Riding, R. Cognitive Styles Analysis—CSA Administration. Learning and Training Technology; Birmingham, UK, 1998.

54. Riding, R. Cognitive Styles Analysis—Research Applications. Learning and Training Technology; Birmingham, UK, 1998.

55. Redmond, J.A.; Mullally, A.P.; Parkinson, A.B. Test-retest reliability of Riding's CSA. In learning styles: Reliability and validity. In Proceedings of the 7th Annual European Learning Styles Information Network Conference, Ghent, Belgium, $26-28$ June 2002.

56. Peterson, E.R.; Deary, I.J.; Austin, E.J. The reliability of Riding's cognitive style analysis test. Personal. Individ. Differ. 2003, 34, 881-891. [CrossRef]

57. Parkinson, A.; Mullally, A.B.; Redmond, J.A. Test-retest reliability of Riding's cognitive styles analysis test. Personal. Individ. Differ. 2004, 37, 1273-1278. [CrossRef]

58. Armstrong, S.J.; Cools, E.; Sadler-Smith, E. The role of cognitive styles in business and management: Reviewing 40 years of research. Int. J. Manag. Rev. 2012, 14, 238-262. [CrossRef]

59. Cools, E.; Pauw, D.A.; Vanderheyden, K. Cognitive styles in an international perspective: Cross-validation of the Cognitive Style Indicator (CoSI). Psychol. Rep. 2011, 109, 59-72. [CrossRef]

60. Cools, E.; Broeck, D.V. The hunt for the heffalump continues: Can trait and cognitive characteristics predict entrepreneurial orientation? J. Small Bus. Strategy 2008, 18, 23-41.

61. Mirjam, K.; Maw, D.F.; Truls, E.; Eva, C. Growth intentions among research scientists: A cognitive style perspective. Technovation 2015, 38, 64-74.

62. Simuth, J.; Sarmany-Schullerb, I. Cognitive style variable in E-learning. Procedia-Soc. Behav. Sci. 2014, 116, 1464-1467. [CrossRef]

63. Brown, S.G.; Tenbrink, A.P.; LaMarre, G. Performance while distracted: The effect of cognitive styles and working memory. Personal. Individ. Differ. 2019, 138, 380-384. [CrossRef]

64. Alalouch, C.; Aspinall, P.; Smith, H. Architects' priorities for hospital-ward design criteria: Application of choice-based conjoint analysis in architectural research. J. Archit. Plan. Res. 2015, 32, 1-22.

65. Glen, S. Non Parametric Data and Tests (Distribution Free Tests). 2014. Available online: https://www.statisticshowto.datascienc ecentral.com/parametric-and-non-parametric-data/ (accessed on 1 April 2021).

66. Jamieson, S. Likert scales: How to (ab) use them. Med. Educ. 2004, 38, 1212-1218. [CrossRef] [PubMed]

67. Alalouch, C. A pedagogical approach to integrate parametric thinking in early design studios. Int. J. Archit. Res. 2018, 12, 162. [CrossRef]

68. Field, A. Discovering Statistics Using IBM SPSS Statistics; SAGE Publications Ltd.: Thousand Oaks, CA, USA, 2013.

69. Kaiser, H. A second generation little jiffy. Psychometrika 1970, 35, 401-415. [CrossRef]

70. Kaiser, H. An index of factorial simplicity. Psychometrika 1974, 39, 31-36. [CrossRef]

71. Bartlett, M. A note on the multiplying factors for various chi square approximations. J. R. Stat. Soc. B 1954, 16, 296-298.

72. Ford, J.; MacCallum, R.; Tait, M. The application of exploratory factor analysis in applied psychology: A critical review and analysis. Pers. Psychol. 1986, 29, 291-314. [CrossRef]

73. Rashid, R. Digital Analytics Decision Trees: CHAID vs. CART. 2017. Available online: https://www.linkedin.com/pulse/digital -analytics-decision-trees-chaid-vs-cart-raymond-rashid/ (accessed on 18 February 2020).

74. Alalouch, C.; Aspinall, P.; Smith, H. On locational preferences for privacy in hospital wards. Facilities 2009, 27, 88-106. [CrossRef]

75. Vermunt, J.; Magidson, J. Latent class analysis. In The Sage Encyclopedia of Social Sciences Research Methods; Sage Publications: Thousand Oaks, CA, USA, 2004; pp. 549-553.

76. Magidson, J.; Vermunt, J. A Nontechnical Introduction to Latent Class Models. 2002. Available online: https://www.statisticali nnovations.com/wp-content/uploads/Magidson2002.pdf (accessed on 1 February 2020).

77. Shulman, L.S. The signature pedagogies of the professions of law, medicine, engineering, and the clergy: Potential lessons for the education of teachers. In Proceedings of the Math Science Partnerships (MSP) Workshop: Teacher Education for Effective Teaching and Learning, Hosted by the National Research Council's Center for Education, Irvine, CA, USA, 6-8 February 2005.

78. McMillan, W.J. Your thrust is to understand how academically successful students learn. Teach. High. Educ. 2010, 15, 1-13. [CrossRef] 